\title{
THE EFFECTS OF ORGANIZATIONAL LEARNING ON FIRM PERFORMANCE THROUGH PRODUCT INNOVATION
}

\author{
*Aihemaituoheti WUJIABUDULA \\ *Cemal ZEHIR \\ *Yildiz Technical University
}

\begin{abstract}
Innovation is a new and wide scoped subject not only for the field of social science, but also research in various fields associated with creativity and ingenuity. Organizational learning has also been a hotspot research subject which has been analysed and put profound importance upon in order to boost firm performance. The main purpose of this study is to determine the relationship between organizational learning and firm performance through the mediating effects of product innovation. In this study, 295 middle and senior managers are selected from firms which are conducting manufacturing industries in Turkey. The collected date is analysed using SPSS 22 statistical package software. The following results are found: product innovation plays mediating effects on the relations between organizational learning and firm performance.
\end{abstract}

Keywords: Organizational Learning, Product Innovation, Firm Performance

\section{INTRODUCTION}

Technological advancements, financial globalization, ever-increasing competition and innovation enforce businesses around the world to find new ways to enhance their performance. The businesses and firms in Turkey, of course, are not exclusive. Improving a firm's performance requires that multiple characteristics be already embedded in a firm. Only focusing on one or several characteristics in business increases the probability of making this firm or business less competitive. In order to stand out from other businesses or firms in a competitive business environment, firms have to generate creative ideas, manufacture ingenious products, remain open to technological developments and keep up with advancements in technology, and also place equal importance on training in new innovations is an essential factor for firms to improve their performance.

Organizational learning has been researched by many scholars who make some references to the concept that organizational learning is certain to yield superior performance if it is implemented properly. To some scholars organizational learning is decomposable into information processing stage or selfregulating process or error-detection and error correction. To some researchers organizational learning includes sets of specific learning foundations or core disciplines.

Not only organizational learning, but also product innovation is also placed high emphasis upon by many researchers in the aim of investigating the effects of product innovation on firm performances. Innovation is a vital organizational strategy for a business or firm to gain a competitive advantage. Innovation has a positive influence on business performance. Product innovation represents the production of new products and services to create markets and new customers to satisfy the market and customers. Product innovation plays an important role not only for firms and sectors, but also is of great importance in the economic level as well. In this context, the study starts with literature review of organizational learning, product innovation and firm performance, then will go to development of hypothesis. Research methodology, analyses results and research model will be put at the second section. The results of the analyses will be discussed and recommendation will be provided for managers and academics at the last section.

\section{LITERATURE REVIEW AND HYPOTHESES}

\section{Organizational Learning}

The early research on organizational learning in the scientific field was conducted by Cyart and March in 1963. Cyart and March noted organizational learning theory in the book named 'A Behavioural Theory of 
the Firm'. According to Cyert and March, organizations learn from experience on the purpose of adapting themselves to the conditions of their environment. In 1995, an article 'Organizational Learning: Observations towards a theory', in which organizational learning was presented at the first time in the title of scientific research, was published by Cangelosi and Dill.

In the year of 1978, Agryris ve Schön, "Organizational Learning: A theory of action perspective", introduced the subject of organizational learning as single loop learning and double loop learning. The other significant studies respectively conducted by Duncan (1974), March and Olsen (1976), Duncan and Weiss (1979). The other representative works of the 80's on organizational learning are: the types of learning conducted by Hedberg (1981), learning system by Shrivastava (1981), regarding organizational learning as the a system of interpretation by Daft and Weick (1984) and in 1985, Fiol and Lyles (1985) enriched and expanded the organizational learning subject through carrying out the research related to the levels of organizational learning. In 2006, Spector and Davidsen carried out a research on organizational learning and noted that organizational learning shares many of the characteristics of individual learning, that learning is about changes that tend to persist and measuring those changes would establish that change has occurred.

Many researches can be found in literature related to organizational learning. In this study, the relationship between organizational learning and firm performance is analysed. In the literature review, organizational learning is defined as the key and as the basis of obtaining sustainable competitive advantages to the firm performance (Martinez-Costa and Jimenez-Jimenez, 2009). In 1999, Baker and Sinkula researched the correlation between organizational learning and firm performance, they found that not only does organizational learning have a direct influence on firm performance, but also they suggested that there are indirect relationships between organizational learning and firm performance. In 2002, Ellinger and other researchers published a paper "The Relationship between the Learning Organization Concept and Firms' Financial Performance: An Empirical Assessment” and analyzed the relationship between organizational learning and firm financial performance. Their research approved that there is a positive and significant relations between organizational learning and a firm's financial performance.

Prieto and Revilla (2006) suggested that non-financial performance could be an intermediate outcome that must be introduced to observe the effects of a firm's learning capabilities, part of which is individual learning, on financial performance. Some other research found in literature suggests the strong correlation between learning at the organizational level and firm performance (Martinez-Costa and Jimenez-Jimenez, 2009).

Organizations which are also well equipped with the flexible and responsive structures provided by organizational learning are able to react to the new challenges and changes much faster than their competitors. Assiduous learning is also of great importance to accommodate the organization or firm's performance enhancement of market information processing activities (Martinez-Costa and JimenezJimenez, 2009). In 2008, Chaveerug also suggested that the great commitment towards learning in organization could compel organizations to achieve their goals more easily. In this study, 4 dimensions of organizational learning are taken into consideration (Calantone, Cavusgil and Zhao, 2002): Intraorganizational knowledge sharing, shared visions, commitment to study and open mindedness.

Intra-Organizational Knowledge Sharing: is the way to disseminate and spreading knowledge and information among different departments in an organization, in which different departments are in a collaborative alliance, share knowledge, and learn from one another. Not only sharing and learning from each other, an organization is also able to improve its "process and products by integrating new insights and knowledge" from another organization, as well. In intra-organizational knowledge sharing, not only should information be disseminated and contributed by the owners, but also it is absorbed by its recipients. Shared organizational knowledge goes along with the systematic re-examination and restructuring to serve as a source off future action.

Shared Vision: indicates the common direction for people in an organization for learning. Shared vision is actualized by a common picture of the future created by mutual interaction between individuals in an organization. Shared visions is constituted by the efforts an organization's personnel is more adaptable, this means, workers in an organization work towards their shared vision with enthusiasm, not because someone requires them to work, but because they are eager to do it. Thus, individual goals align with the 
direction of the organizational goal. Shared vision effects the direction of learning and leads to an increase in the quality of learning (Sinkula et al., 1997: 309). Without shared vision, individual and team learning is meaningless. No shared vision makes individuals and groups desultory, even though they are stimulated or motivated to learn (Calantone et al., 2002: 516)

Commitment to Learning: is the degree to which an organization values and promotes learning, and is likely to foster a learning environment. The committed organizations consider learning to be a significant investment that is important to survival. If the organization makes leaning one of its top priorities, the possibility of learning will increase. Commitment to learning is associated with long-term strategic orientation. Short term investment surely produces long term benefits.

Open-mindedness: refers to the willingness in organizational structure to critically evaluate the organization's operational routine associated with dissemination of information between different departments and to embrace new ideas which are innovative to many people (Calantone, Cavusgil and Zhao, 2002). In order to allow individual knowledge to be continuously renewed, learning that implies open mentality towards ingenuity, flexible solutions, current and future problems is required (Gomez et al., 2005). Lessons learned from previous experiences are likely to be very instrumental in many firms, if they are capable of questioning the mistakes and their results. Organizational learning is enhanced by open mindedness and updating and renewing an old knowledge base (Calantone, Cavusgil and Zhao, 2002).

\section{Product Innovation}

Product innovation is the introduction of a good or service that is new or significantly improved with respect to its characteristics or intended uses. This includes significant improvement in technical specifications, components and materials, incorporated software, user friendliness or other functional characteristics. Product innovation is also defined as the development of new products, changes in design of established products, or use of new materials or components in the manufacture of established products.

Many scholars studied product innovation profoundly, including its dimensions, definitions and effects on firm performance along with host of other topics on this subject. Products with innovative features not only satisfy customers' needs, but also provide firms with more opportunities to expand its market and bring competitive advantages to the firm's implementation of an innovation product (Grulke \& Silber, 2002; Stefik \& Stefik, 2004; Wuyts \& Stremersch, 2004). Several studies also approved that there are strong relationships betweeen product innovation and firm performance (Song \& Parry, 1999; Akgün, Keskin, Byrne, \& Aren, 2007).Akgün and Keskin also studied the effects of product innovation on firm performance, specifically on firms in the Turkish industrial market. They found the correlation between product innovation and firm performance significantly positive (Akgün, Keskin, Byrne, and Aren, 2007). One study carried out in 1993 on Japanese corporations also found that there is a significant correlation between ingenuity and business performance (Deshpandé, Farley, and Webster, 1993). Not every study done on the effects of product innovation on firm performance was positive.

Meyer and Robers (1986) studied the relationship between market newness, technological newness and corporate growth. They found significantly negative correlations between them. In research done on hightechnology electronical firms in Alabama, Yap and Souder (1994) analysed the correlations between unique features as product advantage and new product success. They also noted the correlation between them is negative. From literary review, we can't deny the fact that most of the research supports product innovation as the driving force for firm performance. Hitt et al (1997) also referred in his study and defined product innovation as the doors opening to both global an international competitive advantage by providing the marketplace with new or unique products or services, creating entry barriers that provide the necessary resources to develop innovation via learning, and creating new values that reform the rules of the competitive environment (F.J. Lloréns Montes et al., 2005). An organization's openness, acceptance, and implementation of new ideas, processes, products or services and propensity to change through adopting new technologies, resources, skills and administrative systems reflect its innovation orientation. In other words, its degree of being ready to innovate (Ussahawanitchakit, 2008).

Calantone et al. (2002) also note that firms which are oriented to a full understanding of customer needs, competitors' actions, and technological advancement make it possible for its organizations to gain 
competitive advantage by organizational commitment to learning. Klomp and Van Leeuwen conclude that the innovation contributes significantly to the overall sales performance, productivity (as measured by sales per employee) and employment growth. Darroch (2005) also suggests that managers who want to improve firm performance have to pursue innovation in the current environment. In order to remain competitive, inovation is needed for organizations. Certain organizations stay behind due to a lack of innovation and loss of their competitive position in business world (Darroch, 2005). When we argue about the relationships between product innovation and firm performance, 4 different types of innovations can be found in the OECD Oslo Manual (2005). There are product innovation, process innovation, marketing innovation and organizational innovation. In this article, we mainly focus on the relationship between product innovation and mediating effect of product innovation between organizational learning and firm performance.

\section{Firm Performance}

The definition of firm performance and its measurement constantly challenge scholars due to its complexity, although many researchers found in literature about firm performance. Venkatraman and Ramanujam (1986) offered an enlightening figure of three overlapping concentric circles with the largest representing organizational effectiveness. These broad domains of organizational effectiveness include the medium circle representing business, which include the inner circle representing financial performance. Combs, Crook, and Shook (2005) also published an article in the strategic management Journal 1980 and 2004, in this article they identified 238 empirical studies which used 56 different indicators. Financial performance was used $82 \%$ with accounting measures of profitability being the most common choice. Venkatraman and Ramanujam (1986) put forward a two-dimensional classification of firm performance or business performance. In their study, financial performance and operational performance are put forward, which have to be distinguished between primary and secondary sources of information. Financial measures are associated with accounting measures and the economic performance of a firm. Operational measures are connected to operational success factors that might lead to financial performances like customer satisfaction, quality, market share and new product development (Venkatraman and Ramanujam, 1986). From the point of this study, primary sources are collected form the organization itself while secondary measures are gathered from external or derivative databases.

Firm performance is a multidimensional concept (Murphy et al., 1996) whose indicators can be departmental, such as pertaining to production, finance and marketing (Sohn et al, 2007), or consequential as pertaining to growth and profit (Wolff and Pett, 2006). Another study suggests that firm performance can be measured by both objective and subjective measures (Dawes, 1999; Harris, 2011) Objective measures address to performance indicators that are impartially quantified. Objective measures are usually financial indicators which can be directly collected from organizations via secondary resources. Subjective measures attribute to the judgment assessment of internal or external respondents. Subjective measures include financial and operational indicators (Gonzalez-Benito, 2005).To measure firm performance, objective or subjective measures can be used. Executives normally pay close attention to subjective measures when they evaluate a firm's profitability, sales, market share, customer satisfaction etc. From this point of view, executives usually pay their closest attention on subjective measures instead of objective measures (Garg, Walters, and Priem, 2003). In this study, subjective measures of performance adapted from Venkatraman and Ramanujam (1986) are used. The effect of organizational learning on firm performance through product innovation is measured by subjective measures. Data is collected directly from middle or high level managers or executives of the firms via questionnaires, which means primary sources, are used in this survey.

\section{DEVELOPMENT OF HYPOTHESES}

According to literary review, most of the researchers highlighted the positive relationship between organizational learning and firm performance. Organizational learning is the main factor for firms. Not only is it essential to create new knowledge, but it also enables firms to access external information. Information is the fundamental strategic resource for firms in the process of catching a sustainable competitive advantage. Jian and Hailin (2010) carried out research on 127 various sectors in China, like manufacturing, technological, informatics, financial and chemical sectors etc. They examined the relationship between organizational learning and firms. Organizational learning is examined with 3 
factors like commitment to learning, shared vision, and open-mindedness. Firm performance is measured with marketing performance, human resource effectiveness and new products. The research result is as follows: all the factors of organizational learning has the significantly positive relations with all of the factors of firm performance.

Milia and Birdi (2010) performed a study on 213 different sectors in Australia in production sector, transportation, retail, finance, communication, the health sectors and education etc. They found that individual and group learning have no positive effect on firms' subjective and objective financial performance; but learning at the organizational level has a positive effect on firms' subjective and objective financial performance.

In 2008, Zehir et al. performed an investigation on 18 different sectors in Istanbul (Turkey) and established that there was a significantly positive relationship between organizational learning and firm performance. Garcia-Morales, Llorens-Montes, Verdu-Jover (2006) carried out a study on 900 various sectors in Spain, like food-agriculture industry, import and export and service sector. They noted that there was a significantly positive relationship between organizational learning and firm performance. Carayannis ve Alexander (2002) also performed a study on firms which entered "The Fortune 500" list in 1999 in USA, and they suggested the significantly positive relationship between market performance and learning. Kitapci et al.(2012) also suggest that there was a significantly positive relationship with four dimensions of organizational learning capacity and financial performance. Therefore, from the theoretical background of organizational learning and firm performance, the first hypothesis of this paper suggests that:

Hypothesis 1: Organizational learning has a positive relationship with firm performance.

Innovation and firm performance are complex factors to measure. Many innovation types can be found in literature: marketing innovation, product innovation, process innovation, strategic innovation, organizational innovation and management innovations. etc. In this study, we mainly focus on product innovation. Product innovation is a paramount way in which firms compete and grow (Eisenhardt and Tabrizi, 1995; Wu, 2012). Product innovation harnesses the new knowledge and innovative technology, or can be based on new utilizes and or mixing of existing knowledge or technology. In Oslo Manuel, innovation is that a new or extremely improved product (goods or service) or process, a new marketing method or a new organizational form are realized in the intra-organizational practices or external relationships. In other words, the minimum condition requested for the innovation is that the product, process, marketing or organizational method should be new to (or extremely improved) to the firms. Many researchers carried out studies to measure the relationship between innovation and firm performance. Innovation capability is the most vital determinant of firm performance, much literature review also supports innovation is instrumental to boost firm performance and firms should be innovative in order to survive in a volatile environment. Rhee, Park and Lee (2010) examined the relationship between innovation and firm performance in their study on 333 firms in South Korea; they came to the conclusion that innovation has significantly positive effect on firm performance. In different study carried out on 119 automobile firms by Eren, Yücel and Eren (2010) in Kocaeli (Turkey) also suggests that there is a positive relationship between innovation and business performance.

Matzler, et al. (2008) also performed a study on 300 small and medium sized enterprise in Australia and suggested that product innovation had a significant positive effect on profitability and growth. Zehir and Özsahin (2006) also carried out a study on 73 manufacturing sectors which featured on ISO 100 List in Turkey and suggested that there was a significant positive relationship between innovation and firm performance. Mairesse and Mohnen (2003) performed a study on the firms in Germany, France, England and Spain and found that there was a positive relationship between product innovation and productivity, but there was no any significant relationship between process innovation and firm performance. Thus, the second hypothesis of this article suggests that:

Hypothesis 2: Product Innovation has a positive relation with firm performance.

The mediating role of product innovation between organizational learning and firm performance are also found in literature. Jimenez-Jimenez and Sanz-Valle (2011) carried out a study on 451 manufacturing and service sector in Spain, they found that organizational learning has a positive effect on innovation and firm performance, besides, innovation has a positive effect on firm performance. At the result of the 
study, researchers found that the organizational learning has a stronger effect on innovation compare with the effect of organizational learning on firm performance, and product innovation has a mediating effect between organizational learning and firm performance. Garcia-Morales, Llorens-Montes and Verdu-Jover (2007) also performed a study on the 401 CEOs whose firms are in service and manufacturing sectors in Spain. After the study, not only the significantly positive relationship between organizational learning and firm performance was found, but also they found the positive relationship between innovation and firm performance. Besides, the effect of organizational learning on firm performance was increased through the mediating effect of innovation. Calantone; Cavusgil; Zhao (2002) also performed a study (USA) on $187 \mathrm{R} \& \mathrm{D}$ department manager assistant to determine the relationship between organizational learning, innovation and firm performance. They found that organizational learning has the significant positive relationship with innovation and firm performance. The more organizational learning level increases, the more innovation capability and firm performance enhance. Thus, the third hypothesis of this article suggests that:

H3: Product innovation mediates the relationship between organizational learning and firm performance

\section{METHODOLOGY}

\section{Research Goal}

The main aim of this survey is to determine the mediating effect of product innovation on the relationship between organizational learning and firm performance. Questionnaire is conducted to test the propositions in this field survey.

\section{Sample and Data Collection}

The survey of this study is implemented on 295 middle or senior managers of firms performing manufacturing industry in Turkey. 350 questionnaires were sent by emails or managers were directly asked to fill out the research questionnaires in person, but only 295 middle or senior managers accepted participation in our survey via mail or face-to-face interview. 49 questionnaires were eliminated, because of random answers or $2 / 3$ of the questionnaire were unfilled. Some participants did not meet the requirements of which participants should be middle or senior managers of firms. The SPSS package program was used to analyze the date collected from those 295 questionnaires. The proposed relationship between organizational learning, product innovation and firm performance were tested through regression analyses.

\section{Analyze and Results}

To measure organizational learning, 4 items of the organizational learning scale (Garcia - Morales et al., 2007) are used.

Table 1. KMO and Bartlett's Test

\begin{tabular}{|c|c|c|}
\hline \multicolumn{2}{|c|}{ Kaiser-Meyer-Olkin Measure of Sampling Adequacy. } & 0,938 \\
\hline \multirow[t]{3}{*}{ Bartlett's Test of Sphericity } & Approx. Chi-Square & 4187,288 \\
\hline & df. & 210 \\
\hline & Sig. & 0,000 \\
\hline
\end{tabular}


Table 2. Factor Analysis Results:

\begin{tabular}{lcccc}
\hline & & Number of Items & Scale Format & Cronbah's Alpha \\
All Variable & 24 & LRFa \& LRFb & 0,839 \\
\hline ORGANIZATIONAL LEARNING (OL) & & 4 & LRFa & 0,923 \\
OL1 & 0,786 & & & \\
OL2 & 0,837 & & LRFb & 0,902 \\
OL3 & 0,834 & 0,816 & & \\
OL4 & & & \\
PRODUCT INNOVATION (PI) & 0,777 & & \\
PI1 & 0,676 & & \\
PI2 & 0,756 & & \\
PI3 & 0,680 & & \\
PI4 & 0,628 & & \\
PI5 & 0,635 & & \\
PI7 & 0,615 & & \\
PI8 & & & \\
\hline FIRM PERFORMANCE (FP) & 0,739 & & \\
FP14 & 0,782 & & \\
FP15 & 0,781 & & \\
FP16 & 0,702 & & \\
FP17 & 0,791 & & \\
FP18 & 0,725 & & \\
FP19 & 0,648 & & \\
FP23 & 0,683 & & \\
FP24 & 0,766 & & \\
FP25 & & & \\
\hline
\end{tabular}

Notes: LRFa - Likert Response Format (Five Point: 1 = strongly disagree to 5= Strongly Agree)

LRFb - Likert Response Format (Five Point: 1 = Very Low to 5= Very High)

Firm performance measurement scale is adopted from the marketing and financial performance scales developed by Zahra et al. (2002), Baker and Sinkula (1999) Lynch et al. (2000), in which a total of 35 items are found. The product innovation scale is adopted from Zahra et al (2002), and it contains 8 questions. Overall, 47 items using 5 Likert-type scales are implemented to measure organizational learning, product innovation and firm performance. Those items with factor loading can be seen on Table 1. Also it can be seen from Table 2. The Cranach's Alpha values for each factor exceeds 0,70, which indicates the reliability of scales used in that survey.

\section{Table 3.Construct Construct Means, Standard Deviations, Correlations, and Alpha Coefficients among Model Constructs}

\begin{tabular}{lccccc}
\hline \multicolumn{1}{c}{ Model } & Mean & Standard Division & OL & Correlation Matrix & PI \\
\hline $\begin{array}{l}\text { Organizational } \\
\text { Learning(OL) }\end{array}$ & 15,259 & 3,254 & 1 & & \\
Product Innovation (PI) & 31,759 & 5,390 & $0,644^{* *}$ & 1 & \\
& & & & & \\
Firm Performance (FP) & 33,873 & 6,524 & $0,577^{* *}$ & $0,686^{* *}$ & 1 \\
\hline
\end{tabular}

$\mathrm{P}<0,05$

In order to examine the hypothesis, regression analysis is also applied to test and define the direction of the relationship between organizational learning, product innovation and firm performance. As it is shown in Table 3, it can be seen that both organizational learning and product innovation have a significantly positive relationship with firm performance. Based on Table 4 , organizational learning $(B=0,577$, $\mathrm{P}=0,000$ ) has significant relationship with firm performance. The correlation between product innovation $(B=0,686, P=0,000)$ and firm performance is also significantly positive $(p=0,000)$. As it can be seen in regression model 3, when product innovation is included in regression analyses, the effect of organizational learning on firm performance is automatically reduced, in other words, product innovation $(B=0,537, P=0,000)$ undertakes some effect on firm performance while organizational learning $(B=0,231$, $\mathrm{P}=0,000$ ) reduce its effect on firm performance. Thus, regression analysis results Hypothesis 1 , Hypothesis 2 and Hypothesis 3. 
Table 4: Regression Analysis Results on the mediator of Product Innovation on Organizational Learning and Firm Performance

\begin{tabular}{llllllll}
\hline \multirow{2}{*}{ Models } & $\begin{array}{l}\text { Independent } \\
\text { Variables }\end{array}$ & $\begin{array}{l}\text { Dependent } \\
\text { Variables }\end{array}$ & $\beta$ & Sig. & Adjusted R & F Value & Model Sig. \\
\hline 1 & OL & FP & 0,577 & 0,000 & 0,330 & 130,568 & 0,000 \\
2 & PI & FP & 0,686 & 0,000 & 0,468 & 232,592 & 0,000 \\
3 & OL & PI & 0,644 & 0,000 & 0,412 & 185,258 & 0,000 \\
\multirow{2}{*}{4} & OL & FP & 0,231 & 0,000 & & & \\
\cline { 2 - 5 } & PI & & 0,537 & 0,000 & & 131,312 & 0,000 \\
\hline
\end{tabular}

$\mathrm{P}<0,05$

In compliance with regression analyses results, research model is being shaped as it has been shown at Figure 1 below:

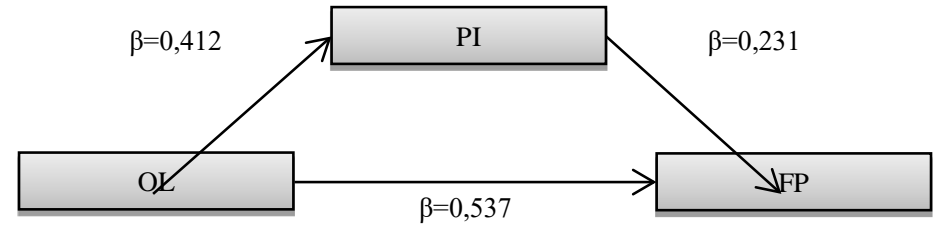

Fig.1 Research Model

\section{CONCLUSION}

This survey, which is conducted on middle and senior managers of firms performing in the manufacturing industry in Turkey, not only puts emphasize on the relationship between organizational learning, product innovation and firm performance, but also determines the mediating effect of product innovation in relation to organizational learning and firm performance. In accordance with the research result, the hypotheses Organizational learning has positive relationship with firm performance, Product Innovation has positive relationship with firm performance and Product Innovation mediates the relationship between organizational learning and product innovation are fully supported by the correlation, regression and factor analyses. Even though much research was carried out in literature to determine the relationship between innovation and firm performance (Calantone; Cavusgil; Zhao, 2002; Garcia-Morales, LlorensMontes and Verdu-Jover, 2007; Jimenez-Jimenez, Sanz-Valle and Hernandez-Espallardo 2008; Dharmadasa, 2009) but the mediating effect of product Innovation on firm performance is researched specifically in Turkey and has correlated with previous studies.

However, this survey is carried out only on companies or firms in Turkey, findings might not be transferable to various other organizations. Further researches should be conducted on middle and senior managers not only from Turkey, but also those from Europe, Asia, Africa or the Middle East etc. regions. Another limitation to this study is that some organizations that had taken part in this survey are not innovation-oriented or those from education institutions, or responders did not qualify to be middle or senior managers of firms. Besides, some answers in questionnaires are not honestly filled out while others are simply ignored. So further researches should be done to examine the relationship between organizational learning and firm performance, or the mediating effect of product innovation on the relations between organizational learning and firm performance. The questionnaires can be filled out by various respondents from different organization to prevent same source biases. 


\section{REFERENCES}

Noruzy, Ali ,Vahid Majazi Dalfard, Behnaz Azhdari, Salman Nazari-Shirkouhi, Aliasghar Rezazadeh (2013), Relationship between transformational leadership, organizational learning, organizational innovation, and organizational performance: An empirical investigation of manufacturing firms. International Journal of Advanced Manufacturing Technology, 64,pp.1073-1085.

Bell .Simon J., Gregory J. Whitwell, Bryan A. School of thought in organizational learning, Lukas Journal of the Academy of Marketing Science. Volume 30, No. 1, pp. 70-86.

Sinkula,James (1994), Market information processing and Organizational learning, Journal of Marketing, 58(1),pp.35-43

Wan, David, Chin Hua Tong, Francis Lee(2005), "Determinants of Firm Innovation in Singapore." Technovation 25, no. 3, pp. 261-68.

Castaneda, D. I. and Rios, M. F.(2007), “From Individual Learning to Organizational Learning.” The Electronic Journal of Knowledge Management Volume 5 Issue 4, pp. 363372

Fiol, C. and Lyles, M. (1985) Organizational learning, Academy of Management Review, 10, 803-813.

Spector, M. J., and Davidsen, P.I. (2006), How can Organizational Learning be Modeled and Measured Evaluation and Program Planning, 29, PP.63-69.

Ellinger, A.D., Ellinger, A.E., Yang, B., Howton, S.W., Baldwin T.T., and Danielson C.C. (2002), The Relationship Between the Learning Organization Concept and Firms' Financial Performance: An Empirical Assessment (and Invited Reaction), Human Resource Development Quarterly, 13(1), pp. 5-29.

Kocoglu Ipek, Imamoglu Salih Zeki, Ince Hüseyin(2011), The relationship between organizational learning and firm performance: the mediating roles of innovation and TQM, Journal of Global Strategic Management,pp.74.

Tuan, Nham P., Khine Tin Zar Lwin (2013), Exploring the Link Between Learning and Firm Performance: an empirical study of private manufacturing firms in Yangon-Myanmar, Asian Academy of Management Journal, Vol.18, No. 2, PP.55-84.

Martinez-Costa, M.,Jimenez-Jimenez, D. (2009), the Effectiveness of TQM: The Key Role of Organizational Learning in Small Businesses, International Small Business Journal, 27, pp. 98-125.

Sinkula JM, Baker WE, Noordewier TA (1997). Framework for market-based organizational learning: linking values, knowledge, and behavior. Journal of Academy Marketing Science ;25(4),pp.305- 318.

Roger J. Calantone, S. Tamer Cavusgil, , Yushan Zhao (2002) , Learning Orientation, Firm Innovation Capability,and Firm Performance, Industrial Marketing Management 31, pp. 515- 524

Akgün, A.E. , H. Keskin, J.C. Byrne, and S. Aren (2007), "Emotional and Learning Capability and Their Impact on Product Innovativeness and Firm Performance,” Technovation, vol. 27: pp.501-513, 2007.

Yap C. M., W.E. Souder(1994), "Factors Influencing New Product Success and Failure in Small Entrepreneurial High-technological Electronics Firms,” The Journal of Product Innovation Management, vol.11, pp. 418-432.

Llorens Montes, F.J., Moreno, A.R., Morales, V.G. (2005), Influence of Leadership and Teamwork Cohesion on Organizational Learning, Innovation and Performance: An Empirical Examination, Technovation, 25, pp. 11591172.

Juliana Bonomi Santos, Luiz Artur Ledur Brito (2012), Toward a Subjective Measurement Model for Firm Performance, Brazilian Admissions Review, Rio de Janeiro, v. 9, Special Issue, art. 6, pp. 95-117

Combs, J. G., Crook, T. R., \& Shook, C. L. (2005). The Dimension of Organizational Performance and Its Implications for Strategic Management Research. In D. J. Ketchen \& D. D. Bergh (Eds.), Research methodology in strategy and management ,pp. 259-286.

Özşahin Mehtap , Zehir Cemal , Acarc A.Zafer (2011), Linking Leadership Style to Firm Performance: the Mediating Effect of the Learning Orientation, Procedia - Social and Behavioral Sciences, Volume 24, PP. 1546-1559 
Atalay Murat, Anafarta Nigun, Sarvan Fulya (2003), The Relationship Between Innovation and Firm Performance:An Empirial Evidence from Turkish Automotive Supplier Industry, Procedia -Social and Behaviral Science 75,pp.226-235

Yang Jian and Lan Hailin (2010), “The Moderating Role of Organizational Learning in the Relationship between Organizational Innovation and Performance”, The 4th International Congerence on Management and Service Science, August 24-26, Wuhan, China .

Lee Di Milia and Kamal Birdi(2010), “The Relationship Between Multiple Levels of Learning Practices and Objective and Subjective Organizational Financial Performance”, Journal of Organizational Behavior,Vol. 31,p.481-498.

Zehir, C., Yılmaz, E., Velioğlu, H. (2008). The Impact of Information Technology Practices and Organizational Learning on Firm Performance. 4th International Strategic Management Conference, July 19-21, Sarajevo, BosniaHerzegovina, 419-434.

Elias G. Carayannis and Jeff Alexander (2002), "Is Technological Learning a Firm Core Competence, When, How and Why A Longitudinal, Multi-Industry Study of Firm Technological Learning and Market Performance”,Technovation, Vol. 22, 2002, p. 639.

Kızıloğlu Mehmet (2015), the Effect of Organizational Learning on Firm Innovation Capability: An Investigation in the Banking Sector, Global Business and Management Research: An International Journal Vol. 7, No. 3

Johnson JD, Meyer ME, Berkowitz JM, Ethington CT, Miller VD (1997). Testing Two Contrasting Structural Models of Innovativeness in a Contractual Network. Human Communication Research; 24(2):320-48.

Rhee, Jaehoon, Taekyung Park and Do Hyung Lee (2010), "Drivers of Innovativeness and Performance for Innovative SMEs in South Korea: Mediation of Learning Orientation”, Technovation, Vol. 30, p. 6575.

Eren, M. Sule, Rahmi Yücel ve S. Selim Eren(2010); "Firma Performansına Etkileri Kapsamında Çevresel Olumsuzluk, Pazar Dinamizmi, Müsteri Odaklılık ve Yenilikçilik Arasındaki iliskilerin incelenmesi”, Journal ofYasar University, Cilt: 18, Sayı: 5, pp. 31023116.

Jimenez-Jimenez, Daniel and Raquel Sanz-Valle (2011), “Innovation, Organizational Learning, and Performance”, Journal of Business Research, Vol. 64, No. 4, p. 408- 417. Garcia-Morales ,V.J., GarciaMorales, Francisco J. Llorens-Montes and Antonio Verdu

Jover (2007), “Influence of Personal Mastery on Organizational Performance through Organizational Learning and Innovation in Large Firmsand SMEs”, Technovation, Vol. 27, p. 547-568.

Garcia Morales VJ, Llorens -Montes FJ, Verdu -Javer AJ. (2007) the Effects of Transformatioanl Leardership on Organizational Performance through Knowledge and Innovation. British Journal of Management 19, pp.299-319

Baker, William E. and SINKULA, James M. (1999) The Synergistic Effects of Market Orientation and Learning Orientation on Organizational Performance, Journal of Academy of Marketing Science, Vol.27 (4), pp.411-427 